\title{
FACTORS INFLUENCING RESIDENTS' PERCEPTIONS, ATTITUDES AND BEHAVIORAL INTENTION TOWARD FESTIVALS AND SPECIAL EVENTS: A PRE-EVENT PERSPECTIVE
}

\author{
Hui $\mathrm{LI}^{1}$, David D. SCHEIN ${ }^{2 *}$, Siva Prasad RAVI ${ }^{3}$, Wei SONG ${ }^{4}$, Yuanyuan GU ${ }^{5}$ \\ ${ }^{1}$ International College of Business and Technology, \\ Tianjin University of Technology, Tianjin, China \\ ${ }^{2}$ Cameron School of Business, University of St. Thomas, Houston, Texas, USA \\ ${ }^{3}$ School of Business, Nipissing University, North Bay, Ontario, Canada \\ ${ }^{4}$ School of Business, Black Hills State University, Black Hills, South Dakota, USA \\ ${ }^{5}$ International College of Business and Technology, Tianjin University of Technology, Tianjin, China
}

Received 03 September 2017; accepted 30 April 2018

\begin{abstract}
This article reports the results of research investigating residents' perceptions, attitudes and behavioral intention (BI) toward sports festivals and special events (FSE) from a pre-event perspective. A structural equation modeling (SEM) was utilized. Two sets of theoretical frameworks have been employed for this study: Social Exchange Theory (SET) and Social Representation Theory (SRT). A quantitative analysis was utilized. Using structural equation modeling (SEM), the authors have identified a strong association between media influence and FSE image evaluation; FSE image evaluation and residents' perceptions; residents' perceptions and attitudes; and residents' attitudes and behavioral intention. However, the study found that social interactions do not have a significant impact on FSE image evaluation. The practical application of this research is that event planners should use media to promote FSE to local residents. This article concludes with the management implications for FSE planners and organizers. Future studies can build on the findings of the paper to generalize this China model for adaption to other countries.
\end{abstract}

Keywords: festivals and special events, marketing, behavioral intention, host city, residents, preevent perspective, image evaluation, structural equation modeling.

JEL Classification: M16, M30, M31.

\section{Introduction}

In recent years, festival and special event (FSE) marketing has gained popularity in China due to the increasing perceptions of the potential financial benefits of events to the host city's economy, including creating employment and encouraging visitation to the host city (Barclay, 2009; Getz, 2012; Chen, Qu, \& Spaans, 2013; Tsaur, Tu, Yen, Wang, \& Liang, 2017;

${ }^{\star}$ Corresponding author. E-mail: scheind@stthom.edu 
Ferrari \& Guala, 2017; Matherly, Arens, \& Arnold, 2018; Parent, Rouillarda, \& Naraineam, 2017), and enhancing the city's competitiveness and creating a destination brand (Lee \& Arcodia, 2011; Choi \& Cho, 2016; Cheng, Wong, Wearing, \& McDonald, 2017; Merrilees, Miller, Ge, \& Tam, 2018). Other potential social benefits such as building social networks and social capital within communities are also recognized (Arcodia \& Whitford, 2006; Dwyer \& Fredline, 2008); FSE has also resulted in improving residents' involvement in green initiatives (Wong, Wan, \& Qi, 2015). FSE marketing has become a useful new tool to promote the image of host cities and is advocated by a number of city governments (Jung, Ineson, Kim, \& Yap, 2015; Maennig \& Vierhaus, 2017). Though there is a growing body of literature on FSE, such literature mainly concentrates on the improvement of FSE's effects in order to attract tourists and event visitors (Rezaei, Mirzaei, \& Abbasi, 2018). Among the extant literature, a majority of these studies have reported on the residents' perception, attitudes and behavioral intention during or after the event's completion, while there is limited empirical investigation from the pre-event perspective.

A key success factor for FSE is the community involvement as the residents play an important role in this whole marketing process. Therefore, the residents' perceptions and attitudes will have a significant impact on their behavioral intention toward the FSE. In order to enhance communities' involvement for hosting events and special festivals, both the city government and event organizers hope that more local residents will participate in pre-event preparations. Hence, it is important for planners to understand the factors that contribute to the positive perception and attitudes of residents toward FSE. The aim of this study is to gain a deeper understanding of the residents' perceptions and attitudes as well as the behavioral intention for the pre-event period by implementing a conceptual model. This study statistically measures the effectiveness of the pre-event marketing process, which makes a significant contribution to the overall literature portfolio in the area of Festivals and Special Events (FSE) marketing.

\section{Literature review}

\subsection{Research on residents' perspective and social exchange theory}

It has been witnessed that cities are increasingly using FSE marketing to improve their image and competitiveness (Getz, 1991; Nunkoo, Ramkissoon, \& Gursoy, 2013; Gursoy, Yolal, Ribeiro, \& Netto, 2017). Since the 1960s, FSE marketing has been studied by numerous scholars in Western countries (Byrd, Bosley, \& Dronberger, 2009; Seetanah \& Sannassee, 2015).The main focus of research on FSE marketing strategies is to assess the potential economic and social benefits on the host city (Bull \& Lovell, 2007; Poudel, Nyaupane, \& Budruk, 2015; Tresidder, 2015). Scholars have achieved significant progress from four different perspectives: Tourists, residents, city governments and other stakeholders (Crompton \& McKay, 1997; F. Yuksel, Bramwell, \& A. Yuksel, 1999; Li \& Lin, 2011; Nunkoo et al., 2013). Among these interested parties, intensive research studies have been carried out on the views of tourists and governments (Nunkoo \& Smith, 2013; Butler \& Aicher, 2015; Nunkoo, 2015). But research on the perspective of residents is still in the embryonic stage, especially in China. That is 
changing now and new research is emerging in this arena (Lorde, Greenidge, \& Devonish, 2011; Li, Hsu, \& Lawton, 2015; Nunkoo \& So, 2016).

Ritchie and Lyons (1987) conducted research on the residents' attitudes based on the social exchange theory (SET). SET was developed by John Thibaut and Harold Kelley (1959). SET is a framework of reference within a number of theories (Homans, 1961; Blau, 1964; Emerson, 1976). It predicts that a person will leave a relationship when he/she perceives that the costs outweigh the perceived benefits (Emerson, 1962; Nye, 1979; Sabatelli, 1984; Sabatelli \& Shehan, 1993). SET theory underpins the development of an understanding of residents' attitudes on FSE activities. Based on this theory, residents often evaluate FSE activities in terms of expected benefits or costs (Wang \& Pfister, 2008). Residents will be willing to participate in the FSE activities and enter into an exchange with the tourists if they can benefit from it without unacceptable costs (Jiang \& Kim, 2015; Kim, Jun, Walker, \& Drane, 2015). Logically, residents who perceive the exchange as beneficial would support FSE development while residents who perceive the exchange as costly to them would be against the proposed FSE image (Ap, 1992; Getz, 1994; Soutar \& McLeod, 1993).

As an important aspect of marketing for the host city, the residents' positive attitudes will provide a benefit by improving the host city's positive image and positively influence the tourists' experiences in the host city (Gursoy, Chi, \& Dyer, 2009; Dai \& Gai, 2011; Gursoy, Chi, Ai, \& Chen, 2011). Therefore, it is crucial to understand the residents' perceived values and attitudes regarding FSE marketing, especially from the pre-event perspective. This is directly associated with the success or failure of the FSE for the host cities.

\subsection{Social representation theory}

Pearce, Moscardo and Ross (1996) suggest that the use of SET to explain residents' perceptions has some drawbacks. People's perceptions are formed within a societal and historical context as much of an individual's knowledge is socially derived, rather than the result of direct experience. Thus, Pearce and his co-authors adopted a related theory: Social Representation Theory (SRT). SRT proposes a collective concept of values, ideas, beliefs, cultures and traditions shared by the group of members in a community. Inspired by Durkheim's (1912) idea of collective representations, Moscovici in 1961 developed this concept into SRT. Social representations are a bundle of organized judgments, attitudes and information with a hierarchical structure that a social group creates with respect to a social object or situation. They are constructed in daily life by individuals through communication and behavior that can serve to create a basis for future reference (Penz, 2006; Moscardo, 2011; J. Andersén \& A. Andersén, 2014; Becken, 2016). SRT emphasizes the importance of social sharing on individual attitudes and behaviors. Scholars have tried to explain residents' different perceptions and attitudes for FSE under the SRT framework. The sources of social representations can be divided into three areas: direct experience of an event, social interaction, and the media (Fredline \& Faulkner, 2000; Li et al., 2015). These three areas are also the factors which influence the residents' evaluations of the FSE activities and affect individual perceptions, attitudes and behaviors (Ying, 2004). 


\section{Hypotheses}

\subsection{The influential factors of social representations}

Based on SRT, residents' evaluations of the FSE activities will be affected by three factors: direct experience of an event, social interaction, and the media. Direct experience of an event provides residents with more information on which to base their perceptions, and this information is more directly under the control of the individual than other sources or factors. However, the immediate research studies the role for FSE marketing from the pre-event perspective, which analyzes how residents' perceptions, attitudes and behaviors are shaped by the effects of FSE marketing even before the FSE starts. The first factor, the direct experience of an event is not relevant to this study since the FSE must occur before this factor can be measured. Therefore, this study focuses on the second and third factors: social interaction and the media.

Social interaction includes interaction with family, friends, colleagues, casual acquaintances, and strangers (Fredline \& Faulkner, 2000). It is closely related to group membership. When direct experience is limited, people can get a social representation from other sources. This study chooses social interaction and the media as two influential factors of residents' evaluations for FSE. The media has the potential to influence evaluations through the actual contents produced and decisions to report or not report particular issues. A number of studies have explored the central role of the image of the FSE presented in the evaluation of FSE. Those residents may feel satisfied if they like the FSE image (Qiao, 2015). Therefore, this study anticipates that social interaction and the media can positively influence residents' evaluation for the FSE image. Based on this theoretical model, the following hypotheses are proposed:

Hypothesis 1: Social interaction is positively correlated with the presentation of the FSE image.

Hypothesis 2: Media is positively correlated with the presentation of the FSE image.

\subsection{Evaluation of FSE image, residents' perceived value and attitudes}

The current literature supports a certain correlation between FSE image and residents' attitudes. The presentation of FSE image will have a positive impact on people's perceptions. This will in turn affect their attitudes regarding FSE activities (Weigelt \& Camerer, 1988; Pearce, 1997; Li, Song, \& Collins, 2014). Using the SET cost-benefit framework, residents evaluate FSE activities via a social exchange. That is, they evaluate it in terms of expected benefits or costs incurred in return for the services provided. Perceived value is a judgment by the residents of the comparison between the benefits and the costs (Jiang \& Kim, 2015). The benefit components of value include economic, social and environmental attributes. Perceived costs are something the residents give up to acquire or consume a product. High perceived costs may stimulate negative attitudes on the part of residents of the host city. For example, they may feel exploited due to increased costs or inconveniences like heavy traffic or noise (Ap, 1992; Wang \& Pfister, 2008). Correspondingly, perceived costs also include economic, social and environmental attributes ( $\mathrm{Tan} \& \mathrm{Fu}, 2012$; Kim et al., 2015). If the residents see the 
promotion for the FSE image as positive, a stronger perceived value may be experienced by them. Positive image presentations may produce higher perceived benefits or it may generate lower perceived costs. In turn, the higher perceived value may generate residents' positive attitudes. Based on this association, the following hypotheses are proposed:

Hypothesis 3: Evaluation of the FSE image is positively correlated with residents' perceived benefits of the FSE.

Hypothesis 4: Evaluation of FSE image is negatively correlated with residents' perceived costs for the FSE.

Hypothesis 5: Residents' perceived benefit of the FSE image is positively correlated with residents' attitudes.

Hypothesis 6: Residents' perceived cost for the FSE image is negatively correlated with residents' attitudes.

\subsection{Residents' attitudes and behaviors}

From a social exchange perspective, attitudes can predict people's subsequent behavioral reactions, and satisfied people are expected to behave positively toward the FSE activities. Several studies have shown that there is a direct link between how residents view different FSE activities and the degree that they decide to participate in the FSE image (Erfurt \& Johnsen, 2003; Zenker, 2011; Jiang \& Kim, 2015). When the residents experience positive emotions from the promotion of the FSEs, they will want to support and participate in these activities (Allen, Long, Perdue, \& Kieselbach, 1988; Cunningham \& Kwon, 2003; Eddosary, Ko, Sagas, \& Kim, 2015). Specifically in the FSE marketing context, behavioral intention is defined as the intention to participate in FSE activities and willingness to participate in city development. Based on this approach, the following hypotheses are proposed:

Hypothesis 7: Residents' attitude toward the FSE image is positively correlated with their intention to participate in FSE activities.

Hypothesis 8: Residents' attitude toward the FSE image is positively correlated with their willingness to participate in host city planning and preparation for FSE activities.

Figure 1 demonstrates the conceptual model developed based on hypotheses 1-8.

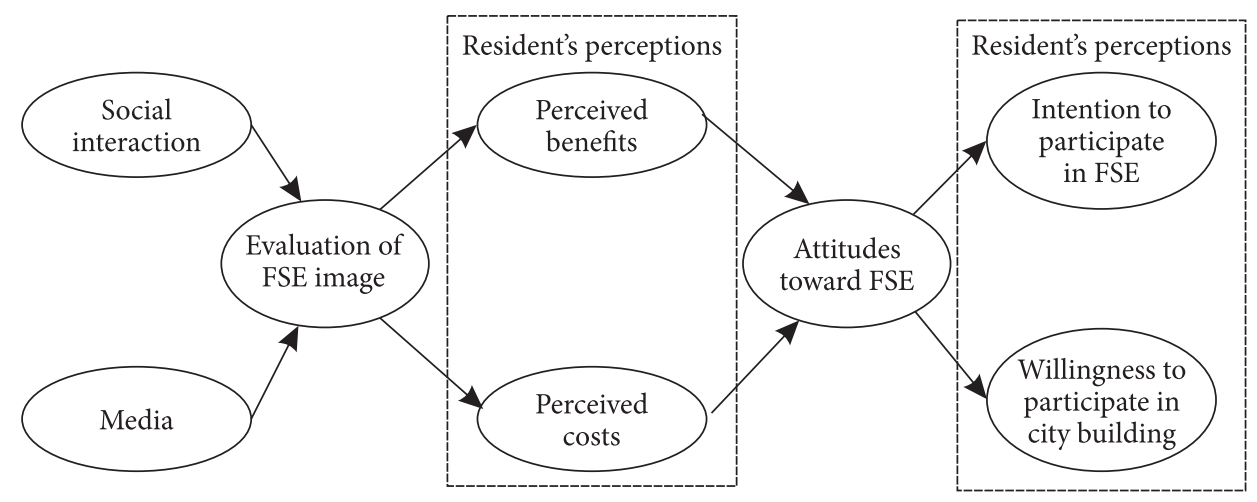

Figure 1. A hypothesized conceptual model 


\section{Research methodology}

\subsection{Study sites and survey design}

This study used the $13^{\text {th }}$ National Games of the People's Republic of China ("NG") in Tianjin in 2017 as the model for examination. NG is the biggest traditional national sports games in China, which are held once every four years. This study focuses on the perceptions and behaviors of residents in Tianjin before the games began. The survey instrument was comprised of nine parts: social interaction, media, evaluation of the FSE image, perceived benefits, perceived cost, attitudes toward the FSE, intention to participate in the FSE, willingness to participate in city development, and certain personal information. The initial measurement scale included 82 items. The authors developed a set of dimensions and used the semantic differential scale to measure the FSE image evaluations. All metrics except for the FSE image evaluations were measured using a Likert scale ranging from 1 to 7 ( 1 = strongly disagree, 7 = strongly agree).

\subsection{Exploratory factor analysis (EFA)}

As scales were being modified and developed for the pre-event context, the authors refined the scales and examined the reliability and validity by using exploratory factor analysis. Data was collected by a self-administered survey; and a convenience sampling method was used to select students at Tianjin University of Technology for the test sample. In total, 151 students responded to the survey. Because of missing and unusable responses, the valid data set featured 124 individuals. KMO (Kaiser-Meyer-Olkin) measure and Bartlett's test of spherecity was used to evaluate the adequacy of data. If the $\mathrm{KMO}>0.6$, then the quality of data was deemed acceptable for this study. In this survey, KMO is higher than 0.8, and Bartlett's test of sphericity is significant $(\mathrm{p}=0.000)$. Thus, the quality of data strongly supports the study. A factor of 0.50 was used as a cut-off to identify items with the highest loadings for inclusion with a factor.

The results of the EFA show that seven items' factor loadings are cross-loaded on two or three factors with a difference of less than 0.1 , and three items did not have significant loadings, so these ten items were dropped. At the end of the scale refinement process, the total number of dimensions was reduced from 82 to 72 . These items produced 12 factors: social interaction, media, evaluation of FSE image, perceived economic benefits, perceived social benefits, perceived environmental benefits, perceived economic costs, perceived social costs, perceived environmental costs, attitudes toward the FSE, intention to participate in FSE, and willingness to participate in host city preparation for the designated FSE image.

\section{Reliability and validity analysis}

After refining the scale, residents of Tianjin were chosen as the sample for collecting data. This study has taken a convenience sampling approach which is one of the non-probability techniques. The street intercepts survey was conducted which could enable us to collect the data from the different segments in a relatively comfortable and safe environment with an 
open public setting. From April 26 to May 5, 2016, the authors distributed questionnaires randomly to residents in the Tianjin Library, Tianjin Galaxy Plaza, Tianjin Railway Station Square, Tianjin Water Park, Tianjin Xiqing University Town and several communities in the Hedong District, Hebei District and Nankai District. Trained fieldworkers contacted participants at the survey locations. The fieldworkers' first screened respondents by asking whether they were residents in Tianjin, to make sure the respondents were in the target sample. All questionnaires were filled in and collected at the scene. A total of 500 questionnaires were distributed and 412 were completed by members of the target sample group. Some questionnaires with missing data were discarded, which resulted in 349 usable questionnaires. The effective response rate was a very strong $69 \%$.

\subsection{Descriptive statistics}

Of respondents, $57.6 \%$ were female and $42.4 \%$ were male. Most respondents (40.4\%) were between 25 and 44 years of age and 51.6\% had some college education. Employees in companies or government departments represented $49.9 \%$. The absolute value of the skewness of all the measured items is less than three, and the absolute value of the kurtosis is less than eight. Therefore, it can be considered that the results of this study are generally consistent with a normal distribution, and can be used for the following analysis.

\subsection{Reliability analysis}

Reliability analysis using SPSS 22.0 showed that all the 12 factors selected had Cronbach's a greater than 0.7 , and corrected item-total correlation (CITC) greater than 0.4 . The reliability values of all the 12 factors are given in Table 1. While conducting an EFA, factors with Cronbach's a greater than 0.6 and CITC greater than 0.4 are considered to have a good internal consistency (Narayan, Rajendran, \& Sai, 2008). Therefore, these results indicate that the scale has good internal consistency.

\subsection{Validity analysis}

In this research, the SEM approach to Confirmatory Factor Analysis (CFA) was adopted using AMOS 17.0 in order to validate the models. The standardized factor loadings, standard error (S.E.), $t$ values and the corresponding average variance extracted (AVE) and construct reliability (CR) are shown in Table 2. According to Bagozzi and Yi (1988), if the explained variance for factors is between 0.5 and 0.95 , and CR for the factors is more than 0.6 , AVE is greater than 0.5 , and $t$ value is greater than 1.96 , this indicates that this scale has high validities. In the current survey analysis, all the standardized factor loadings are greater than 0.5 , and all $t$ values are greater than 1.96. All AVEs are more than 0.9 and CRs are more than 0.8. All square root of the AVE value are greater than the correlation coefficient between the latent variables as displayed in Table 3, below. This shows that the scales have high validities. 
Table 1 . The results of reliability analysis

\begin{tabular}{|c|c|c|c|c|c|c|c|c|c|}
\hline \multicolumn{2}{|c|}{ Factor } & Item & CITC & $\begin{array}{l}\text { Cron- } \\
\text { bach's } \alpha\end{array}$ & \multicolumn{2}{|c|}{ Factor } & Item & CITC & $\begin{array}{l}\text { Cron- } \\
\text { bach's } \alpha\end{array}$ \\
\hline \multirow{3}{*}{\multicolumn{2}{|c|}{$\begin{array}{l}\text { Social } \\
\text { Interaction }\end{array}$}} & B1 & 0.476 & \multirow{3}{*}{0.761} & \multirow{6}{*}{\multicolumn{2}{|c|}{$\begin{array}{l}\text { Per- } \\
\text { ceived } \\
\text { Eco- } \\
\text { nomic } \\
\text { Costs }\end{array}$}} & H1 & 0.554 & \multirow{16}{*}{0.921} \\
\hline & & B2 & 0.645 & & & & $\mathrm{H} 2$ & 0.584 & \\
\hline & & B3 & 0.667 & & & & H3 & 0.518 & \\
\hline \multirow{7}{*}{\multicolumn{2}{|c|}{ Media }} & $\mathrm{C} 1$ & 0.709 & \multirow{7}{*}{0.922} & & & $\mathrm{H} 4$ & 0.481 & \\
\hline & & $\mathrm{C} 2$ & 0.771 & & & & H5 & 0.642 & \\
\hline & & $\mathrm{C} 3$ & 0.780 & & & & H6 & 0.629 & \\
\hline & & C4 & 0.814 & & \multirow{10}{*}{$\begin{array}{l}\text { Perceived } \\
\text { Costs }\end{array}$} & \multirow{5}{*}{$\begin{array}{l}\text { Per- } \\
\text { ceived } \\
\text { Social } \\
\text { Costs }\end{array}$} & I1 & 0.623 & \\
\hline & & C5 & 0.861 & & & & I2 & 0.653 & \\
\hline & & C6 & 0.817 & & & & I3 & 0.546 & \\
\hline & & C7 & 0.563 & & & & I4 & 0.621 & \\
\hline \multirow{9}{*}{\multicolumn{2}{|c|}{$\begin{array}{l}\text { Evaluation of } \\
\text { FSE Image }\end{array}$}} & D1 & 0.639 & \multirow{9}{*}{0.909} & & & I5 & 0.634 & \\
\hline & & D2 & 0.625 & & & \multirow{5}{*}{$\begin{array}{l}\text { Per- } \\
\text { ceived } \\
\text { Envi- } \\
\text { ron- } \\
\text { mental } \\
\text { Costs }\end{array}$} & J1 & 0.665 & \\
\hline & & D3 & 0.716 & & & & $\mathrm{~J} 2$ & 0.648 & \\
\hline & & D4 & 0.722 & & & & $\mathrm{~J} 3$ & 0.725 & \\
\hline & & D5 & 0.618 & & & & $\mathrm{~J} 4$ & 0.676 & \\
\hline & & D6 & 0.734 & & & & J5 & 0.745 & \\
\hline & & D7 & 0.724 & & \multirow{7}{*}{\multicolumn{2}{|c|}{$\begin{array}{l}\text { Attitudes } \\
\text { toward FSE }\end{array}$}} & $\mathrm{K} 1$ & 0.792 & \multirow{7}{*}{0.918} \\
\hline & & D8 & 0.716 & & & & K2 & 0.841 & \\
\hline & & D9 & 0.729 & & & & K3 & 0.766 & \\
\hline \multirow{15}{*}{$\begin{array}{l}\text { Per- } \\
\text { ceived } \\
\text { Ben- } \\
\text { efits }\end{array}$} & \multirow{5}{*}{$\begin{array}{l}\text { Per- } \\
\text { ceived } \\
\text { Eco- } \\
\text { nomic } \\
\text { Benefits }\end{array}$} & N1 & 0.801 & \multirow{15}{*}{0.959} & & & K4 & 0.800 & \\
\hline & & N2 & 0.802 & & & & K5 & 0.791 & \\
\hline & & N3 & 0.812 & & & & K6 & 0.537 & \\
\hline & & N4 & 0.755 & & & & K7 & 0.730 & \\
\hline & & N5 & 0.803 & & \multirow{5}{*}{\multicolumn{2}{|c|}{$\begin{array}{l}\text { Intention to } \\
\text { Participate in FSE }\end{array}$}} & L1 & 0.782 & \multirow{5}{*}{0.932} \\
\hline & \multirow{5}{*}{$\begin{array}{l}\text { Per- } \\
\text { ceived } \\
\text { Social } \\
\text { Benefits }\end{array}$} & $\mathrm{F} 1$ & 0.809 & & & & L2 & 0.794 & \\
\hline & & F2 & 0.808 & & & & L3 & 0.843 & \\
\hline & & F3 & 0.810 & & & & L4 & 0.844 & \\
\hline & & F4 & 0.795 & & & & L5 & 0.833 & \\
\hline & & F5 & 0.707 & & \multirow{6}{*}{\multicolumn{2}{|c|}{$\begin{array}{l}\text { Willingness to } \\
\text { Participate in Host } \\
\text { City Development }\end{array}$}} & M1 & 0.797 & \multirow{6}{*}{0.932} \\
\hline & \multirow{5}{*}{$\begin{array}{l}\text { Per- } \\
\text { ceived } \\
\text { Envi- } \\
\text { ron- } \\
\text { mental } \\
\text { Benefits }\end{array}$} & G1 & 0.747 & & & & M2 & 0.787 & \\
\hline & & G2 & 0.688 & & & & M3 & 0.821 & \\
\hline & & G3 & 0.772 & & & & M4 & 0.844 & \\
\hline & & \multirow{2}{*}{ G4 } & \multirow{2}{*}{0.714} & & & & M5 & 0.765 & \\
\hline & & & & & & & M6 & 0.787 & \\
\hline
\end{tabular}


Table 2. Factor loading, S.E., $t$ value, AVE and CR

\begin{tabular}{|c|c|c|c|c|c|c|c|c|}
\hline \multicolumn{2}{|c|}{ Factor } & Item & $\begin{array}{l}\text { Standard- } \\
\text { ized Factor } \\
\text { Loading }\end{array}$ & S. E. & $\mathrm{t}$ & $\mathrm{P}$ & AVE & $\mathrm{CR}$ \\
\hline \multirow{3}{*}{\multicolumn{2}{|c|}{ Social Interaction }} & B1 & 0.535 & & & & \multirow{3}{*}{0.93} & \multirow{3}{*}{0.82} \\
\hline & & B2 & 0.814 & 0.185 & 9.218 & $* * *$ & & \\
\hline & & B3 & 0.816 & 0.179 & 9.219 & $* * *$ & & \\
\hline \multirow{7}{*}{\multicolumn{2}{|c|}{ Media }} & $\mathrm{C} 1$ & 0.734 & & & & \multirow{7}{*}{0.98} & \multirow{7}{*}{0.86} \\
\hline & & $\mathrm{C} 2$ & 0.796 & 0.071 & 15.059 & $* * *$ & & \\
\hline & & $\mathrm{C} 3$ & 0.807 & 0.073 & 15.28 & $* * *$ & & \\
\hline & & $\mathrm{C} 4$ & 0.855 & 0.075 & 16.277 & $* * *$ & & \\
\hline & & $\mathrm{C} 5$ & 0.9 & 0.071 & 17.202 & $* * *$ & & \\
\hline & & C6 & 0.875 & 0.072 & 16.681 & $* * *$ & & \\
\hline & & $\mathrm{C} 7$ & 0.602 & 0.076 & 11.179 & $* * *$ & & \\
\hline \multirow{9}{*}{\multicolumn{2}{|c|}{$\begin{array}{l}\text { Evaluation of FSE } \\
\text { Image }\end{array}$}} & D1 & 0.602 & & & & \multirow{9}{*}{0.98} & \multirow{9}{*}{0.84} \\
\hline & & D2 & 0.602 & 0.125 & 9.458 & $* * *$ & & \\
\hline & & D3 & 0.766 & 0.124 & 11.269 & $* * *$ & & \\
\hline & & D4 & 0.787 & 0.119 & 11.474 & $* * *$ & & \\
\hline & & D5 & 0.632 & 0.13 & 9.824 & $* * *$ & & \\
\hline & & D6 & 0.793 & 0.117 & 11.531 & $* * *$ & & \\
\hline & & D7 & 0.784 & 0.115 & 11.45 & $* * *$ & & \\
\hline & & D8 & 0.701 & 0.127 & 10.601 & $* * *$ & & \\
\hline & & D9 & 0.765 & 0.12 & 11.259 & $* * *$ & & \\
\hline \multirow{14}{*}{$\begin{array}{l}\text { Perceived } \\
\text { Benefits }\end{array}$} & \multirow{5}{*}{$\begin{array}{l}\text { Per- } \\
\text { ceived } \\
\text { Eco- } \\
\text { nomic } \\
\text { Benefits }\end{array}$} & N1 & 0.873 & & & & \multirow{5}{*}{0.97} & \multirow{5}{*}{0.88} \\
\hline & & N2 & 0.879 & 0.041 & 22.989 & $* * *$ & & \\
\hline & & N3 & 0.84 & 0.044 & 21.051 & $* * *$ & & \\
\hline & & N4 & 0.803 & 0.045 & 19.381 & $* * *$ & & \\
\hline & & N5 & 0.84 & 0.041 & 21.024 & $* * * x$ & & \\
\hline & \multirow{5}{*}{$\begin{array}{l}\text { Per- } \\
\text { ceived } \\
\text { Social } \\
\text { Benefits }\end{array}$} & F1 & 0.858 & & & & \multirow{5}{*}{0.97} & \multirow{5}{*}{0.88} \\
\hline & & $\mathrm{F} 2$ & 0.864 & 0.046 & 21.396 & $* * *$ & & \\
\hline & & F3 & 0.858 & 0.046 & 21.106 & $* * *$ & & \\
\hline & & $\mathrm{F} 4$ & 0.832 & 0.049 & 20.001 & $* * *$ & & \\
\hline & & F5 & 0.736 & 0.054 & 16.4 & $* * *$ & & \\
\hline & \multirow{4}{*}{$\begin{array}{l}\text { Per- } \\
\text { ceived } \\
\text { Envi- } \\
\text { ron- } \\
\text { mental } \\
\text { Benefits }\end{array}$} & G1 & 0.835 & & & & \multirow{4}{*}{0.97} & \multirow{4}{*}{0.88} \\
\hline & & $\mathrm{G} 2$ & 0.83 & 0.052 & 18.552 & $* * *$ & & \\
\hline & & G3 & 0.868 & 0.05 & 19.845 & $* * *$ & & \\
\hline & & G4 & 0.802 & 0.052 & 17.612 & $* * *$ & & \\
\hline
\end{tabular}


End of Table 2

\begin{tabular}{|c|c|c|c|c|c|c|c|c|}
\hline \multicolumn{2}{|c|}{ Factor } & Item & $\begin{array}{l}\text { Standard- } \\
\text { ized Factor } \\
\text { Loading }\end{array}$ & S. E. & $\mathrm{t}$ & $\mathrm{P}$ & AVE & $\mathrm{CR}$ \\
\hline \multirow{16}{*}{$\begin{array}{l}\text { Perceived } \\
\text { Costs }\end{array}$} & \multirow{6}{*}{$\begin{array}{l}\text { Per- } \\
\text { ceived } \\
\text { Eco- } \\
\text { nomic } \\
\text { Costs }\end{array}$} & $\mathrm{H} 1$ & 0.674 & & & & \multirow{6}{*}{0.97} & \multirow{6}{*}{0.84} \\
\hline & & $\mathrm{H} 2$ & 0.691 & 0.087 & 11.282 & $* * *$ & & \\
\hline & & H3 & 0.638 & 0.088 & 10.518 & $* * *$ & & \\
\hline & & $\mathrm{H} 4$ & 0.641 & 0.092 & 10.574 & $* * *$ & & \\
\hline & & $\mathrm{H} 5$ & 0.795 & 0.092 & 12.665 & $* * *$ & & \\
\hline & & H6 & 0.781 & 0.096 & 12.495 & $* * *$ & & \\
\hline & \multirow{5}{*}{$\begin{array}{l}\text { Per- } \\
\text { ceived } \\
\text { Social } \\
\text { Costs }\end{array}$} & I1 & 0.679 & & & & \multirow{5}{*}{0.97} & \multirow{5}{*}{0.85} \\
\hline & & $\mathrm{I} 2$ & 0.722 & 0.081 & 11.939 & $* * *$ & & \\
\hline & & I3 & 0.719 & 0.083 & 11.899 & $* * *$ & & \\
\hline & & $\mathrm{I} 4$ & 0.782 & 0.087 & 12.78 & $* * *$ & & \\
\hline & & I5 & 0.758 & 0.083 & 12.448 & $* * *$ & & \\
\hline & \multirow{5}{*}{$\begin{array}{l}\text { Per- } \\
\text { ceived } \\
\text { Envi- } \\
\text { ron- } \\
\text { mental } \\
\text { Costs }\end{array}$} & $\mathrm{J} 1$ & 0.802 & & & & \multirow{5}{*}{0.97} & \multirow{5}{*}{0.86} \\
\hline & & $\mathrm{J} 2$ & 0.778 & 0.063 & 15.952 & $* * *$ & & \\
\hline & & $\mathrm{J} 3$ & 0.824 & 0.057 & 17.209 & $* * *$ & & \\
\hline & & J4 & 0.763 & 0.063 & 15.564 & $* * *$ & & \\
\hline & & J5 & 0.832 & 0.057 & 17.417 & $* * *$ & & \\
\hline \multirow{7}{*}{\multicolumn{2}{|c|}{ Attitude toward FSE }} & K1 & 0.858 & & & & \multirow{7}{*}{0.98} & \multirow{7}{*}{0.87} \\
\hline & & K2 & 0.908 & 0.043 & 23.585 & $* * *$ & & \\
\hline & & K3 & 0.802 & 0.051 & 18.842 & $* * *$ & & \\
\hline & & K4 & 0.84 & 0.046 & 20.383 & $* * *$ & & \\
\hline & & K5 & 0.831 & 0.042 & 19.996 & $* * *$ & & \\
\hline & & K6 & 0.537 & 0.059 & 10.767 & $* * *$ & & \\
\hline & & K7 & 0.731 & 0.054 & 16.199 & $* * *$ & & \\
\hline \multirow{5}{*}{\multicolumn{2}{|c|}{$\begin{array}{l}\text { Intention to Participate } \\
\text { in FSE }\end{array}$}} & L1 & 0.815 & & & & \multirow{5}{*}{0.97} & \multirow{5}{*}{0.87} \\
\hline & & L2 & 0.825 & 0.056 & 18.112 & $* * *$ & & \\
\hline & & L3 & 0.885 & 0.053 & 20.116 & $* * *$ & & \\
\hline & & L4 & 0.886 & 0.053 & 20.148 & $* * * *$ & & \\
\hline & & L5 & 0.874 & 0.054 & 19.734 & $* * *$ & & \\
\hline \multirow{6}{*}{\multicolumn{2}{|c|}{$\begin{array}{l}\text { Willingness to } \\
\text { Participate in City } \\
\text { Building }\end{array}$}} & M1 & 0.817 & & & & \multirow{6}{*}{0.98} & \multirow{6}{*}{0.88} \\
\hline & & M2 & 0.811 & 0.057 & 17.754 & $* * *$ & & \\
\hline & & M3 & 0.868 & 0.058 & 19.648 & $* * *$ & & \\
\hline & & M4 & 0.889 & 0.055 & 20.393 & $* * *$ & & \\
\hline & & M5 & 0.808 & 0.058 & 17.682 & $* * *$ & & \\
\hline & & M6 & 0.811 & 0.059 & 17.77 & $* * *$ & & \\
\hline
\end{tabular}

Note: ${ }^{* * *}$ means $\mathrm{P}<0.001$. 


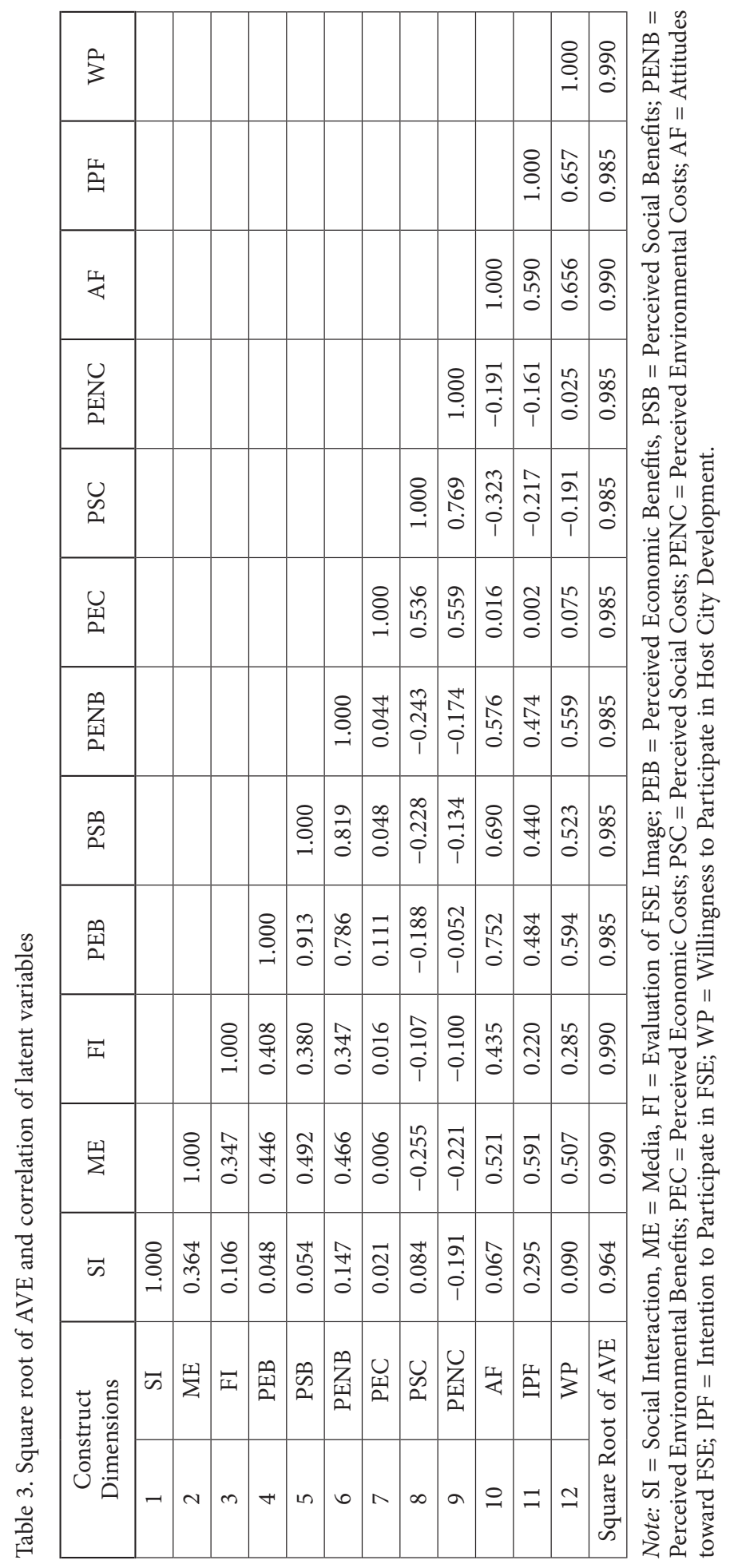




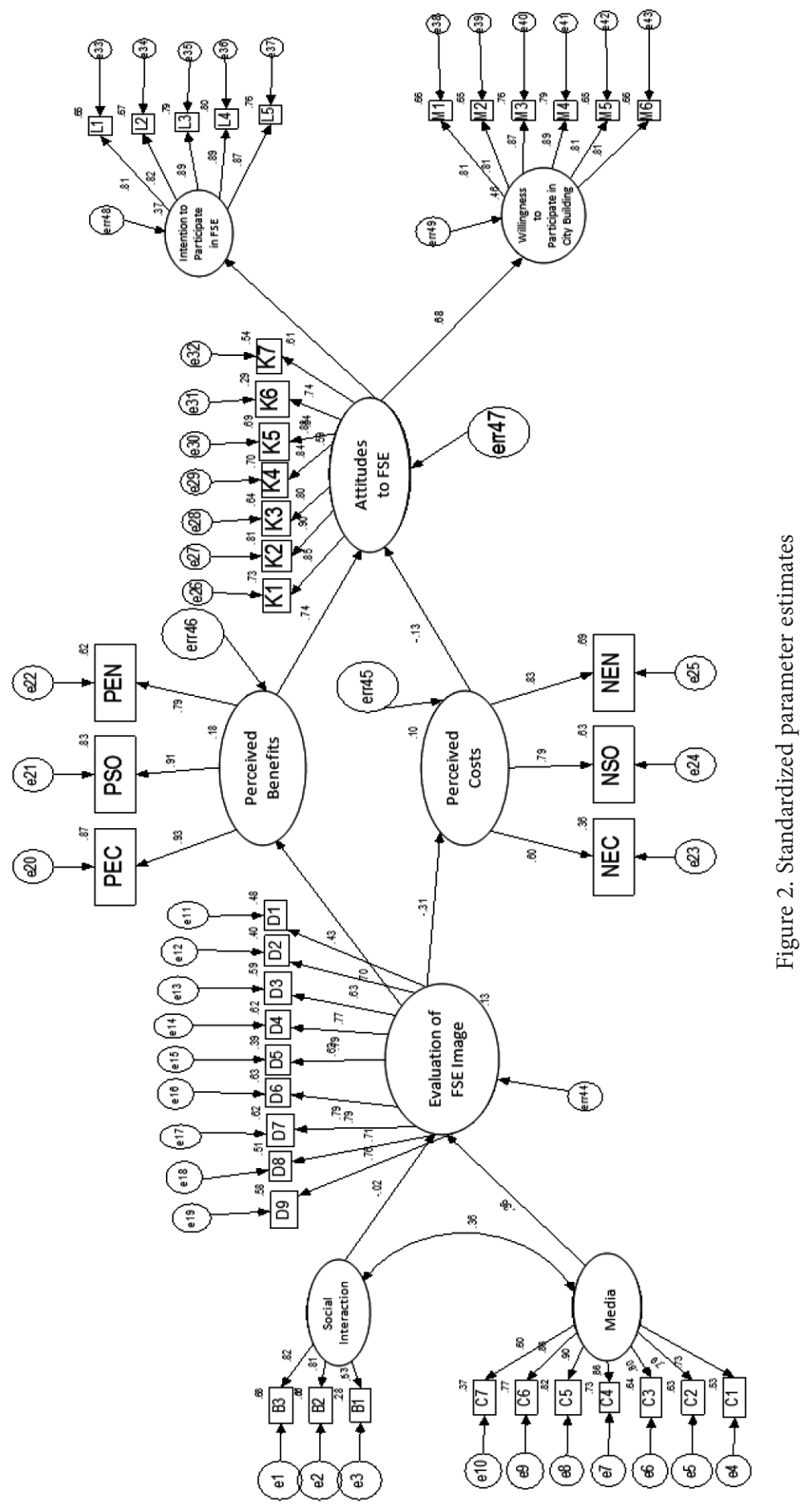




\subsection{Goodness of fit indices}

If there are latent variables to be measured in a model, and especially when multiple dependent variables exist in that model, SEM is a good method to test the fit of the model and the significance of the proposed paths. AMOS 17.0 was used to test the fit of the model. The results revealed a good fit of the model to the data. $\mathrm{X}^{2} / \mathrm{df}=2.741$ (less than 3 ), RMSEA = 0.066 (less than 0.08), IFI $=0.894$ (close to 0.9), and CFI $=0.893$ (close to 0.9 ), all of which indicate an acceptable fit (McQuitty, 2004).

\section{Hypotheses testing}

\subsection{Second-order factor verification}

Following the above results, the perceived benefits were divided into three dimensions: perceived economic benefits, perceived social benefits and perceived environmental benefits. These three dimensions are highly related. The perceived costs also had three dimensions: perceived economic costs, perceived social costs and perceived environmental costs. These three dimensions also are highly related. Therefore, it was possible to develop a second-order factor model which suggests that the first-order factors estimated are actually sub-dimensions of broader and more encompassing second-order factors. According to the results of the second-order confirmatory analysis, the perceived benefits and perceived costs will become the second-order constructs, as they are explained by those first-order constructs. Based on the results, the factor loadings of perceived benefits and perceived costs were calculated instead of the six first-order factor loadings. The model was simplified from 72 to 47 items, which excluded the personal information of the sample participants.

\subsection{Path analysis}

The authors used path analysis to test the research model. For this analysis, a path coefficient was considered significant at the .05 or better probability level. In the survey, the standard path coefficients, $t$ values, and $\mathrm{p}$ values are given in Figure 2 and Table 4 . Except for social interaction and evaluation of the FSE image, all standard errors for the factor loadings and path coefficients in the structural model were near zero. All factor loadings that were tested had t values greater than 1.96, and all of the path coefficients were significant at the .05 level. Therefore, H2, H3, H4, H5, H6, H7, and H8 were supported, but H1 was rejected.

Table 4. Results of hypotheses tests

\begin{tabular}{|c|c|c|c|c|c|c|c|}
\hline & & $\begin{array}{c}\text { Standardized } \\
\text { Coefficient }\end{array}$ & $\begin{array}{l}\text { Standard- } \\
\text { ized Error }\end{array}$ & $\mathrm{t}$ & $\mathrm{P}$ & $\begin{array}{l}\text { Hypo- } \\
\text { thesis }\end{array}$ & Result \\
\hline $\begin{array}{l}\text { Evaluation of } \\
\text { FSE Image }\end{array}$ & $\begin{array}{ll}<--- & \text { Social } \\
\text { Interaction }\end{array}$ & -.023 & 0.069 & -0.363 & 0.717 & $\mathrm{H} 1$ & Reject \\
\hline $\begin{array}{l}\text { Evaluation of } \\
\text { FSE Image }\end{array}$ & <--- Media & .364 & 0.052 & 5.547 & $* * *$ & $\mathrm{H} 2$ & Support \\
\hline
\end{tabular}


End of Table 4

\begin{tabular}{|c|c|c|c|c|c|c|c|c|}
\hline & & & $\begin{array}{c}\text { Standardized } \\
\text { Coefficient }\end{array}$ & $\begin{array}{l}\text { Standard- } \\
\text { ized Error }\end{array}$ & $\mathrm{t}$ & $\mathrm{P}$ & $\begin{array}{l}\text { Hypo- } \\
\text { thesis }\end{array}$ & Result \\
\hline $\begin{array}{l}\text { Perceived } \\
\text { Benefits }\end{array}$ & $<---$ & $\begin{array}{l}\text { Evaluation of } \\
\text { FSE Image }\end{array}$ & .429 & 0.079 & 7.289 & $* * *$ & $\mathrm{H} 3$ & Support \\
\hline Perceived Costs & $<---$ & $\begin{array}{l}\text { Evaluation of } \\
\text { FSE Image }\end{array}$ & -.311 & 0.071 & -4.917 & $* * *$ & $\mathrm{H} 4$ & Support \\
\hline $\begin{array}{l}\text { Attitudetoward } \\
\text { FSE }\end{array}$ & $<---$ & $\begin{array}{l}\text { Perceived } \\
\text { Benefits }\end{array}$ & .741 & 0.048 & 15.199 & $* * *$ & H5 & Support \\
\hline $\begin{array}{l}\text { Attitudetoward } \\
\text { FSE }\end{array}$ & $<---$ & $\begin{array}{l}\text { Perceived } \\
\text { Costs }\end{array}$ & -.125 & 0.051 & -2.879 & 0.004 & H6 & Support \\
\hline $\begin{array}{l}\text { Intention to Par- } \\
\text { ticipate in FSE }\end{array}$ & $<---$ & $\begin{array}{l}\text { Attitude } \\
\text { toward FSE }\end{array}$ & .611 & 0.058 & 10.996 & $* * *$ & H7 & Support \\
\hline $\begin{array}{l}\text { Willingness to } \\
\text { Participate in } \\
\text { City Building }\end{array}$ & $<---$ & $\begin{array}{l}\text { Attitude } \\
\text { toward FSE }\end{array}$ & .678 & 0.051 & 12.324 & $* * *$ & $\mathrm{H} 8$ & Support \\
\hline
\end{tabular}

Note: ${ }^{* * *}$ means $\mathrm{P}<0.001$.

\section{Conclusions}

This study has made the following significant theoretical contribution to the FSE literature. The study has identified the causes in responding to the question of why social interaction does not have a significant effect in the case of NG. With the follow-up semi-structured interviews that were conducted, a possible cause could be the lower awareness level of sports events in China in comparison to Western countries, where sports events are more a part of Westerners' lifestyles.

Another cause is that the city government has only given special attention to the financial benefit side, such as improving the infrastructure and city development initiatives rather than the event marketing per se. This has been in lieu of promotion of the residents' social benefits from sports, for example, or enhancing the sense of the community and the social interaction aspects. Therefore, the motivation of the residents to participate in the NG image is not encouraged.

A third possible cause could be that residents have more FSE choices to select from, with the increase of FSE mega-events in Tianjin. The variety of choices might have reduced the influence of the NG. To date, NG has a low influence on the local residents and this factor might lead to less favorable responses. In previous years, due to the nature of the NG, fewer Chinese were involved.

A fourth cause could be the timing. The survey coincided with the World Economic Forum meeting, where China had a major role. This could have distracted the residents' interest in the NG. On other hand, media promotion does have a positive effect on the residents' evaluations for the FSE image.

The study revealed that evaluation of the FSE image has a significant impact on residents' perceptions of FSE. It demonstrated the residents' evaluations of the FSE image do affect the residents' perceived benefits and perceived costs. In turn, the study demonstrated the 
statically tested results that the residents' perceptions will affect residents' attitudes toward FSE and then affect their behavioral intentions afterwards.

Finally, the study has asserted that media promotion has a positive effect on the residents' evaluations for FSE image, but the effect of social interaction is not significant. Thus, $\mathrm{H} 2$ was supported, but $\mathrm{H} 1$ was not. This is also a new finding for the FSE literature.

The study supports the position that it is necessary for the local government and its administrative team to improve their awareness of social and economic implications of FSE marketing. Local governments should identify and explore the opportunities that involve the host residents in the whole process of the event planning and implementation. The local residents' perception, attitudes and behavioral intention are the key components related to the success of the event marketing. Planners must pay special attention to the residents' perceptions of the FSE before it begins. In this study's results, residents' perceptions of the subject FSE involved three areas: Economic, social, and environmental. The survey results demonstrated that the standardized factor loading of perceived economic benefit is the largest one among the three first-order benefit perception factors.

Concern about the social and cultural dimensions of the FSE should prompt cities to rationally select proposed FSE activities. Not all FSEs improve a city's branding strategy. Only if an FSE image can produce more positive social perceptions, will residents regard it as a good FSE.

Several limitations of the subject study have been identified. First, the scales used are designed in the context of pre-event to test the residents' perceptions, attitudes and behaviors while the literature for pre-event studies is very limited. Second, the sample size is modest. A larger study may produce more significant results for future research. Third, the sample of this study is focused on mainly the urban area of Tianjin. The suburbs and rural participation in the samples is not substantial, which could affect the applicability and accuracy of these findings. Different ages, incomes, and educational backgrounds of potential participants relative to the types of FSE activities may have different effects on the model validation. Future research could help to establish the generalizability of these results by including a broader population mix.

\section{Disclosure statement}

The authors have no competing financial, professional, or personal interests from other parties that are related to the subject of this paper.

\section{Author contributions}

The underlying study and the resulting paper was a true collaborative effort under the general direction of Dr Hui Li as lead director of research.

\section{Funding}

This work was supported by the National Social Science Foundation of China Project: Study on the Influence of Event Marketing on the Host City Brand in the Perspective of City Customers, Grant No. 15BGL085. 


\section{References}

Allen, L. R., Long, P. T., Perdue, R. R., \& Kieselbach, S. (1988). The impact of tourism development on residents' perceptions of community life. Journal of Travel Research, 27(1), 16-21. https://doi.org/10.1177/004728758802700104

Andersén, J., \& Andersén, A. (2014). Deconstructing resistance to organizational change: a social representation theory approach. International Journal of Organizational Analysis, 22(3), 342-355. https://doi.org/10.1108/IJOA-04-2012-0582

Ap, J. (1992). Residents' perceptions on tourism impacts. Annals of Tourism Research, 19(4), 665-690. https://doi.org/10.1016/0160-7383(92)90060-3

Arcodia, C., \& Whitford, M. (2006). Festival attendance and the development of social capital. Journal of Convention and Event Tourism, 8(2), 1-18. https://doi.org/10.1300/J452v08n02_01

Bagozzi, R. P., \& Yi, Y. (1988). On the evaluation of structural equation models. Journal of the Academy of Marketing Science, 16(1), 74-94. https://doi.org/10.1007/BF02723327

Barclay, J. (2009). Predicting the costs and benefits of mega-sporting events: misjudgment of Olympic proportions. Economic Affairs, 29(2), 62-66. https://doi.org/10.1111/j.1468-0270.2009.01896.x

Becken, S. (2016). Peak oil: a hidden issue? Social representations of professional tourism perspectives. Journal of Sustainable Tourism, 24(1), 31-51. https://doi.org/10.1080/09669582.2015.1042484

Blau, P. M. (1964). Exchange and power in social life. New York: John Wiley \& Sons.

Bull, C., \& Lovell, J. (2007). The Impact of hosting major sporting events on local residents: an analysis of the views and perceptions of Canterbury residents in relation to the Tour de France 2007. Journal of Sport \& Tourism, 12(3-4), 229-248. http://dx.doi.org/10.1080/14775080701736973

Butler, B. N., \& Aicher, T. J. (2015). Demonstrations and displacement: social impact and the 2014 FIFA World Cup. Journal of Policy Research in Tourism Leisure and Events, 7(3), 299-313. https://doi.org/10.1080/19407963.2014.997436

Byrd, E. T., Bosley, H. E., \& Dronberger, M. G. (2009). Comparisons of stakeholder perceptions of tourism impacts in rural eastern North Carolina. Tourism Management, 30(5), 693-703.

https://doi.org/10.1016/j.tourman.2008.10.021

Chen, Y. W., Qu, L., \& Spaans, M. (2013). Framing the long-term impact of mega-event strategies on the development of Olympic host cities. Planning Practice \& Research, 28(3), 340-359. https://doi.org/10.1080/02697459.2013.750072

Cheng, M. M., Wong, I. A., Wearing, S., \& McDonald, M. (2017). Ecotourism social media initiatives in China. Journal of Sustainable Tourism, 25(3), 416-432. https://doi.org/10.1080/09669582.2016.1214141

Choi, Y., \& Cho, Y. C. (2016). Exploring factors that affect destination brand in the tourism industry. Journal of Marketing Thought, 3(3), 1-10.

Crompton, J. L., \& McKay, S. L. (1997). Motives of visitors attending festival events. Annals of Tourism Research, 24(2), 425-439. https://doi.org/10.1016/S0160-7383(97)80010-2

Cunningham, G. B., \& Kwon, H. (2003). The theory of planned behavior and intentions to attend a sport event. Sport Management Review (Sport Management Association of Australia \& New Zealand), 6(2), 127-145. https://doi.org/10.1016/S1441-3523(03)70056-4

Dai, L. L., \& Gai, S. J. (2011). Residents' perception on rural event and event tourism impact based on structural equation model: a case study in Changshaoying Village in Beijing. Journal of Beijing University (Natural Science Edition), 47(6), 1121-1128.

Durkheim, E. (1912). The cultural logic of collective representations. In C. Lemert (Ed.), Social theory: the multicultural readings (2010, pp. 94-103). Westview Press, Philadelphia. 
Dwyer, L., \& Fredline, L. (2008). Special sport events-part I. Journal of Sport Management, 22(4), 385391. https://doi.org/10.1123/jsm.22.4.385

Eddosary, M. M., Ko, Y. J., Sagas, M., \& Kim, H. Y. (2015). Consumers' intention to attend soccer events: application and extension of the theory of planned behavior. Psychological Reports, 117(1), 89-102. https://doi.org/10.2466/01.05.PR0.117c13z7

Emerson, R. M. (1976). Social exchange theory. Annual Review of Sociology, 2, 335-362. https://doi.org/10.1146/annurev.so.02.080176.002003

Emerson, R. M. (1962). Power dependence relations. American Sociological Review, 23(1), 31-41. https://doi.org/10.2307/2089716

Erfurt, R. A., \& Johnsen, J. (2003). Influence of an event on a destination's image. Tourism Review, 58(4), 21-27. https://doi.org/10.1108/eb058420

Ferrari, S., \& Guala, C. (2017). Mega-events and their legacy: image and tourism in Genoa, Turin and Milan. Leisure Studies, 36(1), 119-137. https://doi.org/10.1080/02614367.2015.1037788

Fredline, E., \& Faulkner, B. (2000). Host community reactions a cluster analysis. Annals of Tourism Research, 27(3), 763-784.https://doi.org/10.1016/S0160-7383(99)00103-6

Getz, D. (1991). Assessing the economic impacts of festivals and events: research issues. Journal of Applied Recreation Research, 16(1), 61-77.

Getz, D. (1994). Residents' attitudes towards tourism: a longitudinal study of Spey Valley, Scotland. Tourism Management, 15(4), 247-258. https://doi.org/10.1016/0261-5177(94)90041-8

Getz, D. (2012). Event studies: discourses and future directions. Event Management, 16(2), 171-187. https://doi.org/10.3727/152599512X13343565268456

Gursoy, D., Chi , C. G., Ai, J., \& Chen, B. T.(2011). Temporal change in resident perceptions of a megaevent: the Beijing 2008 Olympic games. Tourism Geographies, 13(2), 299-324. https://doi.org/10.1080/14616688.2010.529935

Gursoy, D., Chi, C. G., \& Dyer, P. (2009). An examination of locals' attitudes. Annals of Tourism, 36(4), 723-726. https://doi.org/10.1016/j.annals.2009.06.003

Gursoy, D., Yolal, M., Ribeiro, M. A., \& Netto, A. P. (2017). Impact of trust on local residents' megaevent perceptions and their support. Journal of Travel Research, 56(3), 393-406. https://doi.org/10.1177/0047287516643415

Homans, G. (1961). Social behavior: its elementary forms. New York: Harcourt, Brace \& World.

Jiang, Y., \& Kim, Y. (2015). Developing multi-dimensional green value extending social exchange theory to explore customers' purchase intention in green hotels - evidence from Korea. International Journal of Contemporary Hospitality Management, 23(2), 308-334. https://doi.org/10.1108/IJCHM-08-2013-0383

Jung, T., Ineson, E. M., Kim, M., \& Yap, M. H. T. (2015). Influence of festival attribute qualities on Slow Food tourists' experience, satisfaction level and revisit intention the case of the Mold Food and Drink Festival. Journal of Vacation Marketing, 21(3), 277-288. https://doi.org/10.1177/1356766715571389

Kim, W., Jun, H. M., Walker, M., \& Drane, D. (2015). Evaluating the perceived social impacts of hosting large-scale sport tourism events: scale development and validation. Tourism Management, 48, 21-32. https://doi.org/10.1016/j.tourman.2014.10.015

Lee, I., \& Arcodia, C. (2011). The role of regional food festivals for destination branding. International Journal of Tourism Research, 13, 355-367.https://doi.10.1002/jtr.852

Li, H., Song, W., \& Collins, R. (2014). Post-event visits as the sources of marketing strategy sustainability: a conceptual model approach. Journal of Business Economics and Management, 15(1), 74-95. https://doi.org/10.3846/16111699.2012.701229

Li, H., \& Lin, X. (2011). Research on the long-term influence of festival and special event marketing on the host city: the interrelationship between event image and event satisfaction and intention to visit. Technoeconomics \& Management Research, 9, 110-114. 
Li, X. R., Hsu, C. H. C., \& Lawton, L. J. (2015). Understanding residents' perception changes toward a mega-event through a dual-theory lens. Journal of Travel Research, 54(3), 396-410. https://doi.org/10.1177/0047287513517422

Lorde, T., Greenidge, D., \& Devonish, D. (2011). Local residents' perceptions of the impacts of the ICC Cricket World Cup 2007 on Barbados: comparisons of pre- and post-games. Tourism Management, 32(2), 349-356. https://doi.org/10.1016/j.tourman.2010.03.004

Maennig, W., \& Vierhaus, C. (2017). Winning the Olympic host city election: key success factors. Applied Economics, 49(31), 3086-3099. http://dx.doi.org/10.1080/00036846.2016.1254339

Matherly, R., Arens, Z. G., \& Arnold, T. J. (2018). Big brands, big cities: how the population penalty affects common, identity relevant brands in densely populated areas. International Journal of Research in Marketing, 35(1), 15-33. https://doi.org/10.1016/j.ijresmar.2017.10.001

McQuitty, S. (2004). Statistical power and structural equation models in business research. Journal of Business Research, 57(2), 175-183. https://doi.org/10.1016/S0148-2963(01)00301-0

Merrilees, B., Miller, D., Ge, G., \& Tam, C. (2018). Asian city brand meaning: a Hong Kong perspective. Journal of Brand Management, 25(1), 14-26. https://doi.org/10.1057/s41262-017-0073-1

Moscardo, G. (2011). Exploring social representations of tourism planning: issues for governance. Journal of Sustainable Tourism, 19(4/5), 423-436. https://doi.org/10.1080/09669582.2011.558625

Narayan, B., Rajendran, C., \& Sai, L. P. (2008). Scales to measure and benchmark service quality in tourism industry: a second-order factor approach. Benchmarking: an International Journal, 15(4), 469-493. https://doi.org/10.1108/14635770810887258

Nunkoo, R., \& So, K. K. F. (2016). Residents' support for tourism: testing alternative structural models. Journal of Travel Research, 55(7), 847-861. https://doi.org/10.1177/0047287515592972

Nunkoo, R., Ramkissoon, H., \& Gursoy, D. (2013). Use of structural equation modeling in tourism research: past, present, and future. Journal of Travel Research, 52(6), 759-771.

https://doi.org/10.1177/0047287513478503

Nunkoo, R., \& Smith, S. L. J. (2013). Political economy of tourism: trust in government actors, political support, and their determinants. Tourism Management, 36, 120-132. https://doi.org/10.1016/j.tourman.2012.11.018

Nunkoo, R. (2015). Tourism development and trust in local government. Tourism Management, 46, 623-634. https://doi.org/10.1016/j.tourman.2014.08.016

Nunkoo, R., Gursoy, D., \& Ramkissoon, H. (2013). Developments in hospitality marketing and management: social network analysis and research themes. Journal of Hospitality Marketing \& Management, 22(3), 269-288. http://dx.doi.org/10.1080/19368623.2013.753814

Nye, F. I. (1979). Choice, exchange, and the family. In W. R. Burr, Hill, R., Nye, F. I., \& Reiss, I. (Eds.), Contemporary Theories about the Family (pp. 1-41). New York: The Free Press.

Parent, M. M., Rouillarda, C., \& Naraineam, M. L. (2017). Network governance of a multi-level, multisectoral sport event: differences in coordinating ties and actors. Sport Management Review, 20(5), 497-509. https://doi.org/10.1016/j.smr.2017.02.001

Pearce, D. G. (1997). Competitive destination analysis in Southeast Asia. Journal of Travel Research, 35(4), 16-24. https://doi.org/10.1177/004728759703500403

Pearce, P. L., Moscardo, G. M., \& Ross, G. F. (1996). Tourism community relationships. Oxford: Pergamon Press.

Penz, E. (2006). Researching the socio-cultural context: putting social representations theory into action. International Marketing Review, 23(4), 418-437. https://doi.org/10.1108/02651330610678985

Poudel, S., Nyaupane, G. P., \& Budruk, M. (2015). Stakeholders' perspectives of sustainable tourism development: anew approach to measuring outcomes. Journal of Travel Research, 55(4), 465-480. https://doi.org/10.1177/0047287514563166 
Qiao, G. H. (2015). Research on eco-tourism destination images, tourist satisfaction and destination loyalty using structure equation modeling: a case of World Geopark of Yuntai Mountain in China. Economic Survey, 32(6), 6-10.

Rezaei, N., Mirzaei, R., \& Abbasi, R. (2018). A study on motivation differences among traditional festival visitors based on demographic characteristics, case study: Gol-Ghaltan festival, Iran. Journal of Convention \& Event Tourism, 19(2), 120-137. https://doi.org/10.1080/15470148.2017.1404952

Ritchie, J. R. B., \& Lyons, M. M. (1987). Olympulse III/Olympulse IV: amid-term report on resident attitudes concerning the XV Olympic winter games. Journal of Travel Research, 26(1), 358-369. https://doi.org/10.1177/004728758702600104

Sabatelli, R. M. (1984). The marital comparison level index: a measure for assessing outcomes relative to expectations. Journal of Marriage and the Family, 46, 651-662. https://doi.org/10.2307/352606

Sabatelli, R. M., \& Shehan, C. (1993). Exchange and resource theories. In P. Boss, W. Doherty, R. LaRossa, W. Schuum, \& S. Steinmetz (Eds.), Sourcebook of Family Theories and Methods. New York: Plenum Press. https://doi.org/10.1007/978-0-387-85764-0_16

Seetanah, B., \& Sannassee, R. V. (2015). Marketing promotion financing and tourism development: the case of Mauritius. Journal of Hospitality Marketing \& Management, 24(2), 202-215. https://doi.org/10.1080/19368623.2014.914359

Soutar, G. N., \& McLeod, P. B. (1993). Residents' perceptions on impact of the America's Cup. Annals of Tourism Research, 20(3), 571-582. https://doi.org/10.1016/0160-7383(93)90010-Z

Tan, Y. J., \& Fu, Y. X. (2012). A post evaluation study on residents' perception and attitude towards mega-events: a case of Guangzhou 2010 Asian Games. Journal of Beijing International Studies University, 3, 64-71.

Thibaut, J. W., \& Kelley, H. H. (1959). The social psychology of groups. New York: John Wiley \& Sons.

Tresidder, R. (2015). Experiences marketing: acultural philosophy for contemporary hospitality marketing studies. Journal of Hospitality Marketing \& Management, 24(7), 708-726. https://doi.org/10.1080/19368623.2014.945224

Tsaur, S. H., Tu, J. H., Yen, C. H., Wang, C. H., \& Liang, Y. W. (2017). Evaluation of the 2010 Taipei International Flora Exposition from the perceptions of host-city residents: a new framework for mega-event legacies measurement. Leisure Studies, 36(1), 65-88. https://doi.org/10.1080/02614367.2015.1037786

Wang, Y. A., \& Pfister, R. E. (2008). Residents' attitudes toward tourism and perceived personal benefits in a rural community. Journal of Travel Research, 47(1), 84-93. https://doi.org/10.1177/0047287507312402

Weigelt, K., \& Camerer, C. (1988). Reputation and corporate strategy: a review of recent theory and applications. Strategic Management Journal, 9(5), 443-454. https://doi.org/10.1002/smj.4250090505

Wong, I. A., Wan, Y. K. P., \& Qi, S. S. (2015). Green events, value perceptions, and the role of consumer involvement in festival design and performance. Journal of Sustainable Tourism, 23(2), 294-315. https://doi.org/10.1080/09669582.2014.953542

Ying, T. Y. (2004). Several issues on the application of social representation theory in tourism research. Tourism Tribune, 1, 87-92.

Yuksel, F., Bramwell, B., \& Yuksel, A. (1999). Stakeholder interviews and tourism planning at Pamukkale, Turkey. Tourism Management, 20(3), 351-360. https://doi.org/10.1016/S0261-5177(98)00117-4

Zenker, F. (2011). Experts and bias: when is the interest-based objection to expert argumentation sound. Argumentation, 25(3), 355-370. https://doi.org/10.1007/s10503-011-9226-7 